\title{
Віддалені ускладнення реваскуляризації в пацієнтів із поєднаним атеросклеротичним ураженням екстракраніальних артерій та аорто/ клубово-стегно-підколінного артеріального русла
}

\begin{abstract}
Мета роботи: встановити види та частоту віддалених післяопераційних ускладнень, розвиток яких можна було б попередити, застосувавши способи та методи оперативного втручання у складі реконструкції аорто/клубово-стегно-підколінного артеріального русла.

Матеріали і методи. Прослідковано віддалені результати хірургічного лікування 491 пацієнта протягом 2006 - 2017 рр. Хірургічне втручання виконано 341 (69,4 \%) пацієнту із атеросклеротичною оклюзією аорто-стегнової зони, 3 яких у 248 хворих мало місце порушення кровотоку по стегно-підколінному сегменті. Проведено операційне лікування у 150 (30,6 \%) пацієнтів з приводу оклюзивно-стенотичного ураження клубово-стегнового сегмента, з яких у 94 мало місце порушення кровотоку по стегно-підколінному артеріальному руслі. У 92 (18,7 \%) пацієнтів діагностовано гемодинамічно значимий стеноз екстракраніальних артерій, з них у 75 хворим було проведено операційне втручання на судинах шиї в умовах хірургічного лікування атеросклеротичного ураження аорто/клубово-стегно-підколінного артеріального русла.

Результати досліджень та їх обговорення. Після 491 реконструктивного операційного втручання на аорто/клубово-стегнопідколінному артеріальному руслі у віддаленому післяопераційному періоді діагностовано 139 (28,3 \%) пізніх ускладнень. Серед них у 42 (30,9 \%) пацієнтів розвинувся пізній тромбоз бранші аорто/клубово-біфеморального алопротеза та пізній тромбоз клубово-стегнового сегмента контрлатеральної нижньої кінцівки, у 11 (7,9 \%) пацієнтів діагностовано несправжні аневризми дистального та проксимального анастомозів аорто/клубово-біфеморального алошунта, у 78 (56,1 \%) встановлено наростання хронічної ішемії нижніх кінцівок (ХАН ІІІА-Б ст. за класифікацією Fontaine R. з врахуванням критеріїв Європейської робочої групи (1992)), у 8 (5,8 \%) - пізні інфекційні ускладнення у вигляді нориці ділянки дистального анастомозу.

Розвиток таких пізніх ускладнень, як тромбоз клубово-стегнового сегмента (6 спостережень) контрлатеральної нижньої кінцівки; пізній тромбоз однієї з бранш аорто-біфеморального алошунта (5 спостережень) в результаті блокування оклюзивним процесом анастомозів ПАС і ГАС із низхідною артерією коліна, підколінною артерією та гомілковими артеріями; несправжня аневризма проксимального анастомозу (2 спостереження) аорто-біфеморального алошунта як результат формування анастомозу в межах обмеженого кровопостачання країв серединного аортотомічного розрізу, чому можна запобігти застосувавши способи та методи операційного втручання у складі аорто/клубово-біфеморального алошунтування.

За наявності гемодинамічно значимого атеросклеротичного стенозу екстракраніальних артерій у пацієнтів із атеросклеротичною оклюзією аорто/клубово-стегно-підколінного артеріального русла необхідно провести операційне втручання на судинах шиі до або одночасно із хірургічним втручанням на аорто/клубово-стегно-підколінній зоні.
\end{abstract}

Ключові слова: облітеруючий атеросклероз; реваскуляризація; ускладнення реконструктивних втручань.

Постановка проблеми і аналіз останніх досліджень та публікацій. Незважаючи на сучасні досягнення судинної хірургії, частота порушень прохідності реконструйованих артерій залишається високою як у ранньому, так і у віддаленому післяопераційному періоді [6]. Ускладнення пізнього післяопераційного періоду спостерігаються у 7,9 - 34,1 \% пацієнтів [2, 3]. До найбільш частих ускладнень віддаленого післяопераційного періоду відносять тромбози артерій та шунтів, несправжні аневризми анастомозів, інфекційні ускладнення із поширенням процесу на судинні експлантати [4, 5]. Поряд з цим, діагностуються ряд віддалених ускладнень, що розвиваються в результаті не застосування деяких способів та методів операційного втручання у складі реконструктивних операцій на магістральних артеріях $[1,7]$.

Мета роботи: встановити види та частоту віддалених післяопераційних ускладнень, розви- ток яких можна було б попередити, застосувавши способи та методи операційного втручання у складі реконструкції аорто/клубово-стегно-підколінного артеріального русла.

Матеріали і методи. Прослідковано віддалені результати хірургічного лікування 491 пацієнта протягом 2006 - 2017 рр. Хірургічне втручання виконано 341 (69,4 \%) пацієнту із атеросклеротичною оклюзією аорто-стегнової зони, з яких у 248 хворих мало місце порушення кровотоку по стегно-підколінному сегменті. Проведено операційне лікування 150 (30,6 \%) пацієнтів з приводу оклюзивно-стенотичного ураження клубово-стегнового сегмента, з яких у 94 мало місце порушення кровотоку по стегно-підколінному артеріальному руслі. На час первинного хірургічного втручання у 227 пацієнтів діагностовано хронічну артеріальну недостатність (ХАН) ІІІА, ІІІБ ст. (за класифі- 
кацією Fontaine R. з врахуванням критеріїв Європейської робочої групи (1992)), у 189 - хронічна критична ішемія нижніх кінцівок (ХКІНК) ІІІБ IV ст., у 89 - ХАН ІІБ ст.. У 92 (18,7 \%) пацієнтів діагностовано гемодинамічно значимий стеноз екстракраніальних артерій, з них у 75 хворим було проведено операційне втручання на судинах шиї в умовах хірургічного лікування атеросклеротичного ураження аорто/клубово-стегно-підколінного артеріального русла.

У віддаленому післяопераційному періоді (2 4 місяць) у трьох (3,3 \%) пацієнтів, яким не було проведено операційне втручання з приводу гемодинамічно значимого стенозу екстракраніальних артерій при хірургічному лікуванні атеросклеротичної оклюзії аорто/клубово-стегно-підколінного, діагностовано гостре порушення мозкового кровотоку.

У віддаленому післяопераційному періоді у оперованих пацієнтів діагностовано 139 (28,3 \%) пізніх ускладнень. Серед них у 42 (30,9 \%) пацієнтів розвинувся пізній тромбоз бранші аорто/клубово-біфеморального алопротеза та пізній тромбоз клубово-стегнового сегмента контрлатеральної нижньої кінцівки, у 11 (7,9%) пацієнтів діагностовано несправжні аневризми дистального та проксимального анастомозів аорто/клубово-біфеморального алошунта, у 78 (56,1 \%) встановлено наростання хронічної ішемії нижніх кінцівок (ХАН IIIA-Б ст. за класифікацією Fontaine R. 3 врахуванням критеріїв Європейської робочої групи (1992)), у 8 (5,8 \%) - пізні інфекційні ускладнення у вигляді нориці ділянки дистального анастомозу.

Із 42 спостережень пізнього тромбозу у 31 (73,8 \%) пацієнта в строки між 21 та 64 місяцем після реваскуляризаційної операції на аорто/клубово-стегно-підколінному артеріальному руслі розвинувся пізній тромбоз бранші аорто-біфеморального алопротеза. Причиною цього процесу у 23 (74,2 \%) випадках була гіперплазія неоінтими в умовах атеросклеротичного процесу, що призвело до стенозування дистального анастомозу, у 8 (25,8 \%) - несправжня аневризма дистального анастомозу аорто-біфеморального алопротеза.

В 6 (19,4 \%) спостереженнях в строки між 5 i 13 місяцем після реваскуляризаційної операції на клубово-стегновому сегменті розвинувся тромбоз клубово-стегнового артеріального русла контрлатеральної нижньої кінцівки. Первинна однобічна реконструкція клубово-стегнового сегмента призводить до перерозподілу потоку крові в артеріальне русло із нижчим судинним опором - в артеріальне русла реваскуляризованого клубово-стегнового сегмента. Зниження об’єму крово- току, його сповільнення і високий периферичний судинний опір - фактори, що сприяють розвитку тромбозу клубово-стегнового артеріального русла контрлатеральної нижньої кінцівки.

У 5 (11,9 \%) спостереженнях в проміжку між 2 5 місяцем пізнього післяопераційного періоду розвинувся тромбоз бранші аорто/клубово-стегнового алопротеза. У всіх спостереженнях при первинній реконструкції аорто/клубово-стегнового сегмента проводили формування дистального анастомозу в умовах поширеної оклюзії поверхневої артерії стегна (ПАС) із включенням у кровотік глибокої артерії стегна (ГАС). Для досягнення вказаної мети проведено розширену профундопластику ГАС латкою за Martin (8 спостережень) і профундопластикy за Waibel (одне спостереження). В післяопераційному періоді оклюзивний процес ПАС, що сягав підколінної артерії, сприяв блокуванню анастомозів ГАС із низхідною артерією коліна, підколінною артерією та гомілковими артеріями, що створило умови до поступового погіршення кровотоку по ГАС і сприяло розвитку тромбозу бранші аорто/ клубово-стегнового алопротеза.

У 11 (7,9 \%) пацієнтів діагностовано несправжні аневризми дистального і проксимального анастомозу аорто/клубово-біфеморального алошунта. Причиною розвитку несправжньої аневризми дистального анастомозу (8 спостережень) вважаємо надмірну ендартеректомію в умовах кальцинозу артеріальної стінки. Причиною розвитку несправжньої аневризми проксимального анастомозу (2 спостереження) вважаємо формування його в межах обмеженого кровотоку країв серединної аортотомії в умовах атеросклеротичного ураження артеріальної стінки. Діаметр аорти на рівні несправжньої аневризми був межах 45 і 51 мм.

У 78 (56,1 \%) пацієнтів після 2,7 року віддаленого післяопераційного періоду діагностовано наростання хронічної ішемії нижніх кінцівок (ХАН ІІБ ст. - 41 спостереження, ХАН IIIА ст. - 29 спостережень, ХАН IIIA-Б ст. - 8 спостережень за класифікацією Fontaine R. 3 врахуванням критеріїв Європейської робочої групи (1992)). Посилення хронічної ішемії нижніх кінцівок відбувалось в результаті прогресування атеросклеротичного процесу з переважним ураженням стегно-гомілкового артеріального русла.

У 8 (5,8 \%) спостереженнях з 8-17 місяця віддаленого післяопераційного періоду діагностовано пізні інфекційні ускладнення у вигляді сформованої нориці ділянки дистального анастомозу. Первинна реконструкція аорто/клубово-стегнопідколінного сегмента відбувалась в умовах ХАН III А та III В ст. 
У наведених спостереженнях: пізній тромбоз клубово-стегнового сегмента (6 спостережень) контрлатеральної нижньої кінцівки: пізній тромбоз однієї з бранш аорто-біфеморального алошунта (5 спостережень) в результаті блокування оклюзивним процесом ПАС анастомозів ГАС із низхідною артерією коліна, підколінною артерією та гомілковими артеріями; несправжня аневризма проксимального анастомозу (2 спостереження) аорто-біфеморального алошунта як результат формування анастомозу в межах (серединна аортотомія ) обмеженого кровопостачання країв аортотомічного розрізу можна було б запобігти застосувавши способи та методи операційного втручання у складі аорто/клубово-біфеморального алошунтування.

Результати досліджень та їх обговорення. При проведенні аорто-біфеморального алошунтування слід створити умови для оптимального функціонування проксимального анастомозу аорто-біфеморального протеза. При досягненні мети аортотомія передньої стінки інфраренального відділу черевної аорти формується у вигляді повздовжнього овалу. При цьому розмір в середній частині овалу складає 0,8 - 1,0 діаметра аорти, а повздовжній - до 2,5 розміру середньої частини овалу. Наведені параметри анастомозу між аортою та алопротезом, сформованого за типом кінець алопротеза в бік аорти, наближують гемодинаміку по анастомозу до гемодинамічної характеристики аорти. Слід вказати, що формування анастомозу відбувається на рівні видаленого овального сегмента передньої стінки аорти в межах вищої васкуляризації країв аортотомічного овалу, що значно посилює опірність силі кровотоку по аорті і дає можливість запобігти розвитку несправжньої аневризми проксимального анастомозу аорто-біфеморального протеза.

При однобічній атеросклеротичній оклюзії клубового артеріального русла і діагностиці стенотичного атеросклеротичного процесу (65 71 \%) контрлатерального клубового артеріального сегмента показано проведення аорто-біфеморального шунтування. Стенотичний процес клубового сегмента контрлатеральної нижньої кінцівки сприяє підвищенню периферійного судинного опору і формує високу пікову систолічну швидкість по загальній клубовій артерії на рівні 180 205 см/с. При відновленні кровобігу по оклюзованому клубово-стегновому сегменті відбувається перерозподіл кров'яного потоку у напрямку русла із нижчим периферійним судинним опором. За умови вищого периферійного судинного опору як результату критичного стенотичного процесу клубового сегмента контрлатеральної нижньої кінцівки, перерозподілу кровотоку створюються умови для формування тромботичного процесу в судинному руслі вказаної нижній кінцівки. Наведені обставини вказують, що при однобічній атеросклеротичній оклюзії клубового артеріального русла і виявленому стенотичному атеросклеротичному процесі (65 - 71 \% і вище) контрлатерального клубового артеріального сегмента показано проведення аорто-біфеморального алошунтування (патент на корисну модель № 115930).

В умовах поширеної оклюзії ПАС придатність ГАС до її реконструкції і формуванню з останньою анастомозу із алошунтом протеза вважали стеноз понад 60 \% або оклюзія гирла або стовбура ГАС з прохідною або забезпеченою прохідністю шляхом проведення ендартеректомії середньої і дистальної порцій артерії. В таких спостереженнях застосовується розширена профундопластика ГАС за допомогою латки за Martin або профундопластика за Waibel. B першому випадку формується “протяжний” анастомоз бранші алопротеза із ГАС, а при проведенні профундопластики за Waibel формується “прямий” анастомоз “кінецьв-кінець“ між браншою алопротеза і ГАС, що відсічена на рівні біфуркації ЗАС.

При багаторівневій атеросклеротичній оклюзії аорто/клубово-стегно-підколінного артеріального русла після проведення аорто-біфеморального алошунтування слід провести сонографічне дослідження на рівні глибокої артерії стегна та тібіоперинеального стовбура (ТПС). При показнику пікової систолічної швидкості (ПСШ) і індексу резистентності (IP) на рівні ГАС нижчому, відповідно, за $(43,7 \pm 6,1)$ см/с і $(0,58 \pm 0,09)$ у.о. та показнику ПСШ і IP на рівні ТПС нижчому, відповідно, за $(32,9 \pm 2,8)$ см/с і $(0,50 \pm 0,08)$ у.о. показано проведення стегно-дистальної реконструкції (патент на корисну модель № 115930). Зниження рівня ПСШ та IP на ГАС і ТПС відбувається за рахунок блокування оклюзивним процесом стегно-підколінного сегмента анастомозів ГАС із низхідною артерією коліна, підколінною артерією та гомілковими артеріями. Для створення задовільних умов функціонування аорто/клубово-стегнового алошунта/протеза, попередження розвитку його тромбозу при зниженні рівня ПСШ та IP на ГАС і ТПС, відповідно, на 22 - 25 \% і 32 - 35 \% нижче за показники норми показано проведення стегно-дистальної реваскуляризації артеріального русла нижньої кінцівки.

На функціональну спроможність колатералей ГАС із артеріями підколінно-гомілкової зони при 


\section{З ДОСВІДУ РОБОТИ}

стенотино-оклюзійному процесі поверхневої артерії стегна може вказувати величина індексу забезпечення глибоко стегново-підколінного сегмента (ІЗГСПС), який враховує систолічний тиск вище i нижче колінного суглоба. Паказник ІЗГСПС нижче 0,25 вказує на хороший поза обструкцію ПАС колатеральний кровотік до підколінної ділянки. Рівень показника ІЗГСПС вище за 0,25 вимагає проведення стегно-дистальної реваскуляризації артеріального русла нижньої кінцівки.

Після 491 реконструктивного операційного втручання на аорто/клубово-стегно-підколінному артеріальному руслі у віддаленому післяопераційному періоді діагностовано 139 (28,3 \%) пізніх ускладнень. Розвиток таких пізніх ускладнень, як тромбоз клубово-стегнового сегмента (6 спостережень) контрлатеральної нижньої кінцівки; пізній тромбоз однієї з бранш аорто-біфеморального алошунта (5 спостережень) в результаті блокування оклюзивним процесом ПАС анастомозів ГАС із низхідною артерією коліна, підколінною артерією та гомілковими артеріями; несправжня аневризма проксимального анастомозу (2 спостереження) аорто-біфеморального алошунта як результат формування анастомозу в межах обмеженого кровопостачання країв серединного аортотомічного розрізу, чому можна запобігти застосувавши способи та методи операційного втручання у складі аорто/клубово-біфеморального алошунтування.

За наявності гемодинамічно значимого атеросклеротичного стенозу екстракраніальних артерій у пацієнтів із атеросклеротичною оклюзією аорто/ клубово-стегно-підколінного артеріального русла

\section{СПИСОК ЛІТЕРАТУРИ}

1. Белов Ю. В. Повторные реконструктивные операции на аорте и магистральных артеріях / Ю. В. Белов, А. Б. Степаненко. - М. : “Медицинское информационное агентство”, $2009-176$ c.

2. Венгер I. К. Превентивні операції у віддаленому післяопераційному періоді у пацієнтів з реконструкцією аортостегнового сегмента / I. К. Венгер, С. Я. Костів, А. Р. Вайда // Шпитальна хірургія. - 2014. - № 3. - С. 54-56.

3. Губка В. А. Повторные реконструкции у больных облитерирующим атеросклерозом с отдаленными осложнениями / А. В. Губка // Патология. - 2012. - № 2 (25). - С. 43-45.

4. Гудз І. М. Реконструктивна і ендовазальна хірургія ін- необхідно провести операційне втручання на судинах шиї до або одночасно із хірургічним втручанням на аорто/клубово-стегно-підколінній зоні.

Висновки. Розвиток пізніх ускладнень діагностовано у 139 (26,9 \%) пацієнтів із реконструкцією аорто/клубово-стегнового зони, серед яких у 36 (27,3 \%) спостереженнях розвинувся пізній тромбоз бранші аорто-біфеморального алопротеза та у 6 пацієнтів (4,6 \%) - пізній тромбоз клубово-стегнового сегмента контрлатеральної нижньої кінцівки, у 10 (7,6 \%) пацієнтів діагностовано несправжні аневризми дистального (8) і проксимального (2) анастомозів аорто/клубово-біфеморального алошунта. У 78 (56,1 \%) встановлено наростання ішемії нижніх кінцівок (ХАН ІІІА-Б ст. за класифікацією Fontaine R. 3 врахуванням критеріїв Європейської робочої групи (1992)), у 8 (6,1 \%) - пізні інфекційні ускладнення у вигляді нориці ділянки дистального анастомозу.

У віддаленому післяопераційному періоді (2 - 4 місяць) у трьох (3,3 \%) пацієнтів, яким не було проведено операційне втручання з приводу гемодинамічно значимого стенозу екстракраніальних артерій при хірургічному лікуванні атеросклеротичної оклюзії аорто/клубово-стегно-підколінного, розвинулось гостре порушення мозкового кровотоку.

Застосовуючи деякі способи та методи операційного втручання у складі аорто/клубово-біфеморального алошунтування можна запобігти у 9,9 \% спостереженнях розвиток окремих видів пізніх ускладнень реконструкції аорто/клубовостегно-підколінного артеріального русла.

\section{REFERENCES}

1. Belov, Yu.V., \& Stepanenko, A.B. (2009). Povtornye rekonstruktyvnye operatsii na aorte i magistralnykh arteriyakh [Repeated reconstructions in patients with atherosclerosis obliterans with long-term complications]. Moscow: "Meditsinskoe informatsyonnoe agentstvo" [in Russian]. фраренальної аорти та артерій нижніх кінцівок / І. М. Гудз, К. Бальцер. - Івано-Франківськ, 2004. - 224 с.

5. Повторні реконструктивні втручання на черевній частині аорти та периферичних артеріях / А. Б. Доміняк, Ю. Л. Ящук, Г. Г. Влайков, А. В. Ратушняк // Серце і судини. - 2005. - № 1. - С. 56-57.

6. Кобза I. І. Хірургічне лікування пацієнтів при інфікуванні судинних протезів аорто-стегнової зони / I. І. Кобза, Т. Г. Сорока, Р. А. Жук // Клінічна хірургія. - 2004. - № 4 -5. - С. 89-90.

7. Профундопластика при хронічній ішемії нижніх кінцівок / В. І. Русин, В. В. Корсак, В. В. Русин [та ін.]. - Ужгород : Всеукраїнське державне видавництво “Карпати”, 2018. - 180 с.

2. Venher, I.K., Kostiv, S.Ya., \& Vaida, A.R. (2014). Preventyvni operatsii u viddalenomu pisliaoperatsiinomu periodi uchasnykamy rekonstruktsii aorto-stehnovoho sehmentu [Preventive operations in the remote postoperative period in patients with reconstruction of the aorto-femoral segment]. Shpytalna khirurhiia - Hospital 
Surgery, 3, 54-56 [in Ukrainian].

3. Gubka, V.A. (2012). Povtornyye rekonstruktsii u bolnykh obliteriruyushchim aterosklerozom s otdalennymi oslozhneniyami [Repeated reconstructions in patients with atherosclerosis obliterans with long-term complications]. Patologiya - Pathology, 2 (25), $43-45$ [in Russian].

4. Hudz, I.M., \& Baltser, K. (2004). Rekonstruktyvna i endovazalna khirurhiia infrarenalnoi aorty ta arterii nyzhnikh kintsivok [Reconstructive and endovascular surgery of infrarenal aorta and arteries of the lower limbs]. Ivano-Frankivsk [in Ukrainian].

5. Dominiak, A.B., Yashchuk, Yu.L., Vlaikov, H.H., \& Ratushniak, A.V. (2005). Povtorni rekonstruktyvni vtruchannia na cherevnii chastyni aorty ta peryferychnykh arteriiakh
[Reconstructive intervention on the abdominal aorta and peripheral arteries]. Sertse i sudyny - Heart and Vessels, 1, 5657 [in Ukrainian].

6. Kobza, I.I., Soroka, T.H., \& Zhuk, R.A. (2004). Khirurhichne likuvannia patsiientiv pry infikuvanni sudynnykh proteziv aortostehnovoi zony [Surgical treatment of patients with infections of vascular prostheses of the aorto-femoral zone]. Klinichna khirurhiia - Clinical Surgary, 4-5, 89-90 [in Ukrainian].

7. Rusyn, V.I., Korsak, V.V., Rusyn, V.V., Horlenko, F.V., Kopolovets, I.I., Mashura, V.V., \& Lanhazo, O.V. (2018). Profundoplastyka pry khronichnii ishemii nyzhnikh kintsivok [Profundoplasty in chronic lower limb ischemia]. Uzhhorod: Vseukrainske derzhavne vydavnytstvo "Karpaty” [in Ukrainian].

Отримано 09.01.2019

Електронна адреса для листування: venger@tdmu.edu.ua

I. K. VENHER, M. O. HUSAK, S. YA. KOSTIV, N. I. HERASYMIUK, S. A. YEMIASHEVA

I. Horbachevsky Ternopil State Medical University

\section{THE REMOTE COMPLICATIONS OF REVASCULARIZATION IN PATIENTS WITH COMBINED ATHEROSCLEROTIC AFFECTION OF EXTRACTIONAL ARTERIES AND AORTO/ILIAC-FEMORAL- POPLITEAL ARTERIAL BED}

The aim of the work: to establish the types and frequency of remote postoperative complications, the development of which could be prevented by applying the ways and methods of surgical intervention in the reconstruction of the aorto/iliac-femoral-popliteal arterial bed.

Materials and Methods. The remote results of surgical treatment of 491 patients during 2006-2017 were studied. 341 (69.4 \%) patients with atherosclerotic occlusion of the aortic-femoral area were subjected to surgical intervention, of whom 248 patients had a violation of the flow in the femoral-popliteal segment. Operative treatment was performed in 150 (30.6 \%) patients with occlusivestenotic affection of iliac-femoral segment, of which 94 had violations of the blood flow along the hip-popliteal arterial line. In 92 (18.7\%) patients, hemodynamically significant stenosis of extracranial arteries was diagnosed, of whom 75 patients underwent surgical intervention on the neck vessels in conditions of surgical treatment of atherosclerotic lesion of the aorto/iliac-femoral-popliteal arterial bed.

Results and Discussion. After 491 reconstructive surgical interventions on the aorto/iliac-femoral-popliteal arterial line in the remote postoperative period, 139 (28.3\%) of late complications were diagnosed. Among them, late thrombosis of the aorto/iliac-femoral alloprosthesis and late thrombosis of iliac-femoral segment of the contralateral lower limb developed in 42 (30.9\%) patients; false aneurysms of the distal and proximal anastomosis of the aorto/iliac-femoral alloshunt in 11 (7.9 \%) were diagnosed in 78 (56.1\%) patients; the increasing of chronic lower limb ischemia was established (ChAI IIIA-Bstage according to the classification of Fontaine R. taking into account the criteria of the European Working Group (1992)), the late infectious complications in the form of a fist in the region of distal anastomosis were diagnosed in 8 (5.8\%) patients. Development of such late complications as thrombosis of the iliacfemoral segment (6 observations) of the contralateral lower limb; late thrombosis of one of the branches of aorta-bifemoral aloshunt (5 observations) as a result of blocking by the occlusive process of anastomoses of the superficial femoral artery and the profound femoral artery with the descending artery of the knee, popliteal artery and tibial arteries; the false aneurysm of proximal anastomosis (2 observations) of the aorto-femoral aloshunt, as a result of the formation of anastomosis within the limits of limited blood supply to the edges of the medial aortotomic incision, can be prevented by applying ways and methods of surgical intervention in the composition of the aorto/iliac-bifemoral aloshunting.

In the presence of hemodynamically significant atherosclerotic stenosis of extracranial arteries in patients with atherosclerotic occlusion of the aorto/iliac-femoral-popliteal arterial line, surgical intervention on the vessels of the neck should be performed before or simultaneously with the surgical intervention on the aorta/iliac-femoral-popliteal zone.

Key words: obliteration atherosclerosis; revascularization, complications of reconstructive interventions. 


\section{И. К. ВЕНГЕР, М. О. ГУСАК, С. Я. КОСТИВ, Н. И. ГЕРАСИМЮК, С. А. ЕМЯШЕВА}

ГВУз “Тернопольский государственный медицинский университет имени И. Я. Горбачевского МОз Украины”

\section{ОТДАЛЕННЫЕ ОС.ЛОЖНЕНИЯ РЕВАСКУЛЯРИЗАЦИИ У ПАЦИЕНТОВ С СОЧЕТАЮЩИМСЯ АТЕРОСКЛЕРОТИЧЕСКИМ ПОРАЖЕНИЕМ ЭКСТРАКРАНИАЛЫНЫХ АРТЕРИЙ И АОРТО/ ПОДВЗДОІШНО-БЕДРЕННО-ПОДКОЛЕННОГО АРТЕРИАЛЬНОГО РУС.ЛА}

Цель работы: установить виды и частоту отдаленных послеоперационных осложнений, развитие которых можно было бы предупредить, применив способы и методы оперативного вмешательства в составе реконструкции аорто/подвздошно-бедренно-подколенного артериального русла.

Материалы и методы. Прослежены отдаленные результаты хирургического лечения 491 пациента в течение 2006 - 2017 гг. Хирургическое вмешательство проведено 341 (69,4 \%) пациенту с атеросклеротической окклюзией аорто-бедренной зоны, из которых в 248 больных имело место нарушение кровотока по бедро-подколенном сегменте. Проведено операционное лечение в 150 (30,5 \%) пациентов по поводу оклюзивно-стенотического поражения подвздошно-бедренного сегмента, из которых в 94 имело место нарушение кровотока по бедренно-подколенном артериальном русле. В 92 (18,7 \%) пациентов диагностирован гемодинамически значимый стеноз экстракраниальных артерий, из них 75 больным было проведено оперативное вмешательство на сосудах шеи в условиях хирургического лечения атеросклеротического поражения аорто/подвздошно-бедренно-подколенного артериального русла

Результаты исследований и их обсуждение. После 491 реконструктивных оперативных вмешательств на аорто/подвздошнобедренном-подколенном артериальном русле в отдаленном послеоперационном периоде диагностировано 139 (28,3 \%) поздних осложнений. Среди них у 42 (30,9 \%) пациентов развился поздний тромбоз бранши аорто/подвздошно-бифеморального аллопротеза и поздний тромбоз подвздошно-бедренного сегмента контралатеральной нижней конечности, у 11 (7,9 \%) пациентов диагностированы ложные аневризмы дистального и проксимального анастомозов аорто/подвздошно-бифеморального аллошунта, у 78 (56,1%) установлено нарастание хронической ишемии нижних конечностей (ХАН Ша-Б ст. по классификации Fontaine R. с учетом критериев Европейской рабочей группы (1992)), у 8 (5,8 \%) - поздние инфекционные осложнения в виде свища участка дистального анастомоза.

Развитие таких поздних осложнений, как тромбоз подвздошно-бедренного сегмента (6 наблюдений) контралатеральной нижней конечности; поздний тромбоз одной из бранш аорто-бифеморального аллошунта (5 наблюдений) в результате блокирования оклюзионным процессом анастомозов ПАБ и ГАБ с нисходящей артерией колена, подколенной артерии и берцовыми артериями; ложная аневризма проксимального анастомоза (2 наблюдения) аорто-бифеморального аллошунта как результат формирования анастомоза в пределах ограниченного кровоснабжения краев срединного аортотомичного разреза, что можно предотвратить применив способы и методы оперативного вмешательства в составе аорто/подвздошно-бифеморального аллошунтирувания.

При наличии гемодинамически значимого атеросклеротического стеноза экстракраниальных артерий у пациентов с атеросклеротической окклюзией аорто/подвздошно-бедренно-подколенного артериального русла необходимо провести оперативное вмешательство на сосудах шеи до или одновременно с хирургическим вмешательством на аорто/подвздошно-бедренноподколенной зоне.

Ключевые слова: облитерирующий атеросклероз; реваскуляризация; осложнения реконструктивных вмешательств. 